\title{
PODĄŻAJĄC EKOLINGWISTYCZNYMI ŚLADAMI JUBILATA, PROFESORA STANISŁAWA PUPPLA: CZY NAUCZYCIEL JĘZYKA ANGIELSKIEGO I JEGO KOMPETENCJE JEZYKOWO-KOMUNIKACYJNE W ŚRODOWISKU SZKOLNYM SA WCIĄŻ ISTOTNE WE WSPÓŁCZESNYM ZGLOBALIZOWANYM ŚWIECIE?
}

JUDYTA FILAR-PIECZKOWSKA

Nauczyciel ma wptyw na wieczność. Nie jest bowiem w stanie określić, gdzie kończy się jego oddziatywanie.

(H.B. Adams)

\section{Globalizacja - zjawisko społeczno-kulturowo-językowe}

Świat w XXI wieku dzięki rozwojowi technologii, przepływowi informacji i komunikacji bez barier, dynamicznemu rozwojowi transportu stał się jak nigdy dotąd otwartą przestrzenią bez granic. Przestrzeń ta stanowi ekosystem żywiołowej wymiany m.in. gospodarczej, kulturowej, językowej, religijnej, na poziomie indywidualnym, społeczności oraz na poziomie globalnym. Ta dynamika wielokierunkowego przenikania idei, wzorców, stylów spowodowała wrażenie jakim jest „kurczenie się świata". Człowiek bez żadnych problemów może dowiedzieć się o aktualnościach 
z drugiego krańca świata, kupić produkt zaprojektowany w USA, wyprodukowany w Kambodży, a dystrybuowany z Holandii, czy komunikować się on-line z osobą zza oceanu lub na biegunie.

Jednym ze zjawisk, które powstały na skutek procesu „kurczenia się świata”, a także które jednocześnie ten proces intensyfikują jest globalizacja. Przy czym samo zjawisko globalizacji poprzez oddziaływanie na wiele dziedzin życia i nauki doczekało się wielu definicji. Wśród tych definicji, które podkreślają ukierunkowanie procesu na uniwersalizację i wymiar społeczny, wymienić można twierdzenie Tobera (2000: 14), iż globalizacja to tendencja do „upowszechniania się w społeczeństwie światowym jednolitych norm i wartości i/lub identycznych rozwiązań instytucjonalnych". Co ciekawe, wraz z pojęciem globalizacji pojawia się często pojęcie społeczeństwa globalnego lub społeczeństwa światowego. Na przykład Albrow wskazuje, iż globalizacja „odnosi się do tych wszystkich problemów, w wyniku których narody świata zostają włączone w jedno światowe społeczeństwo, społeczeństwo globalne (Kempny, 1998: 241). W konsekwencji należy więc mieć na uwadze współzależność społecznych oddziaływań. Wszelkie działania lokalne mogą mieć skutek globalny i odwrotnie - to co ma miejsce na arenie światowej może wywierać wpływ na skalę mikro (określonej społeczności lub/i jednostki). Cytując Giddensa „globalizacja to intensyfikacja stosunków społecznych o światowym zasięgu, które łączy różne lokalności w taki sposób, że lokalne wydarzenia kształtowane są przez zdarzenia zachodzące $w$ odległości wielu tysięcy mil i same na nie oddziałują" (Kempny, 1998: 242).

W kontekście edukacji globalizacja przyniosła i w dalszym ciągu przynosi wiele korzyści, ale i wiele niepokojących konsekwencji. Dzięki niej uczniowie i nauczyciele posiadają nieograniczony dostęp do informacji, źródeł, aktualności, zasobów o edukacyjnych treściach, a także otwartą przestrzeń komunikacji z całym światem i możliwość wymiany idei, wzorców językowych i kulturowych. Umożliwia również analizę problemów dotyczących sfery kulturowej, politycznej, społecznej i ekonomicznej w skali ogólnoświatowej np. takich zagadnień jak globalne ocieplenie, dostęp do nielegalnych treści w Internecie, nietolerancja, ksenofobia, zanieczyszczenie środowiska, itp. (zob. Cybal-Michalska i Gmerek, 2015: 12).

Natomiast zatrważającym efektem globalizacji w wymiarze społeczno-kulturowo-językowym wydaje się „tendencja ujednolicania”, co w kontekście edukacyjnym może prowadzić do „modelowania ujednoliconych mas” w środowisku szkolnym w celu przygotowania przyszłego optymalnego pracownika zglobalizowanej gospodarki.

Dodatkowo we wszystkich sferach życia tj. politycznej, gospodarczej, społecznej i językowej panuje zasada - „duży może więcej”. Uprzywilejowana pozycja bogatszych ekonomicznie państw i społeczności powoduje dominację ich wartości, wzorców i tendencji społecznych, a także dominację ich języka rodzimego na arenie międzynarodowej. 


\subsection{Globalizacja językowa}

W jaki sposób dochodzi do ekspansji jednego języka przy jednoczesnym osłabieniu innego wyjaśnić może zjawisko kontaktów językowych oraz towarzyszące mu procesy, efekty i zagrożenia (zob. Puppel i Puppel, 2005).

W ,przestrzeni języków naturalnych” lub inaczej „puli zasobów językowych”, lub jeszcze inaczej ujmując, ,globalnej arenie języków naturalnych" (Puppel, 2009: 97; tłumaczenie własne - J.F-P.) panuje ciągła dynamika wielokierunkowych kontaktów językowych rozumianych jako sytuacje, w których komunikatorzy jednego języka naturalnego używają innego języka naturalnego. Jednocześnie języki te wzajemnie na siebie oddziałują, a nawet konkurują ze sobą. Wynik takich „starć” uzależniony jest od kondycji uczestników, która w kontekście języków naturalnych odnosi się do tężyzny języka (ang. 'natural language robustness'). Konkurencja ta może mieć przebieg zarówno pozytywny, jak i negatywny. Przebieg procesu konkurencji językowej ma wymiar negatywny, jeżeli w wyniku kontaktu językowego dochodzi do systematycznej dominacji jednego języka o większej tężyźnie (język inwazyjny) np. języka angielskiego nad innym o mniejszej tężyźnie (język gospodarza). Długotrwały proces lingwopresji zewnętrznej (ang. 'external linguopressure') może doprowadzić nawet do wyginięcia języka gospodarza w procesie zwanym 'samobójstwem języka' (ang. 'language siucide') lub 'morderstwem języka'(ang. 'language murder') (ibid.). Odwrotny proces - pozytywny przebieg konkurencji językowej - owocuje wzmocnieniem języka naturalnego, który staje się językiem dominującym. Niebezpieczną stroną tych zjawisk jest wyeliminowanie na zawsze języków naturalnych charakteryzujących się słabszą tężyzną na rzecz jednego języka globalnego. Ekolingwiści podają zatrważające dane o przyszłości języków naturalnych, z których wynika, że tylko połowa dziś istniejących przetrwa w następnym stuleciu (ibid.).

\section{Nauczyciel języka angielskiego i jego kompetencja językowo-komunikacyjna w kontekście globalizacji językowej}

Kontekst nauczania języków nierodzimych ${ }^{1}$ w szkołach, a w szczególności najbardziej popularnego języka angielskiego, stanowi przykład kontaktu językowego wymagającego szczególnej uwagi i troski, ponieważ proces edukacji szkolnej kształtuje świadomość całego młodego pokolenia na następnych kilkadziesiąt lat. Sposób, w jaki drugi język jest przedstawiany i egzekwowany w porównaniu do języka rodzimego na zajęciach lekcyjnych, na długo (może na całe życie) pozostaje w pamię-

\footnotetext{
${ }^{1}$ Język nierodzimy $\mathrm{w}$ terminologii ekolingwistycznej odnosi się do języka innego niż język ojczysty czyli rodzimy (termin proponowany przez S. Puppla).
} 
ci uczniów, co z kolei niesie za sobą poważne konsekwencje w sposobie postrzegania tychże języków, a następnie ich pozycji wśród wszystkich języków naturalnych (Filar-Pieczkowska, 2014).

Biorąc pod uwagę model kompetencji językowo-komunikacyjnej opracowany w oparciu o model wg Morreale'a, Spitzberga i Barge'a (2007) przedstawiony w pracy doktorskiej autorki niniejszego artykułu oraz badania przeprowadzone w ramach tejże pracy, wydaje się słusznym przyjrzeć się roli nauczyciela i jego zasobom językowo-komunikacyjnych w ekosystemie szkolnym podczas nauczania języka angielskiego jako języka nierodzimego.

Osoba komunikująca się

Osoba komunikująca się
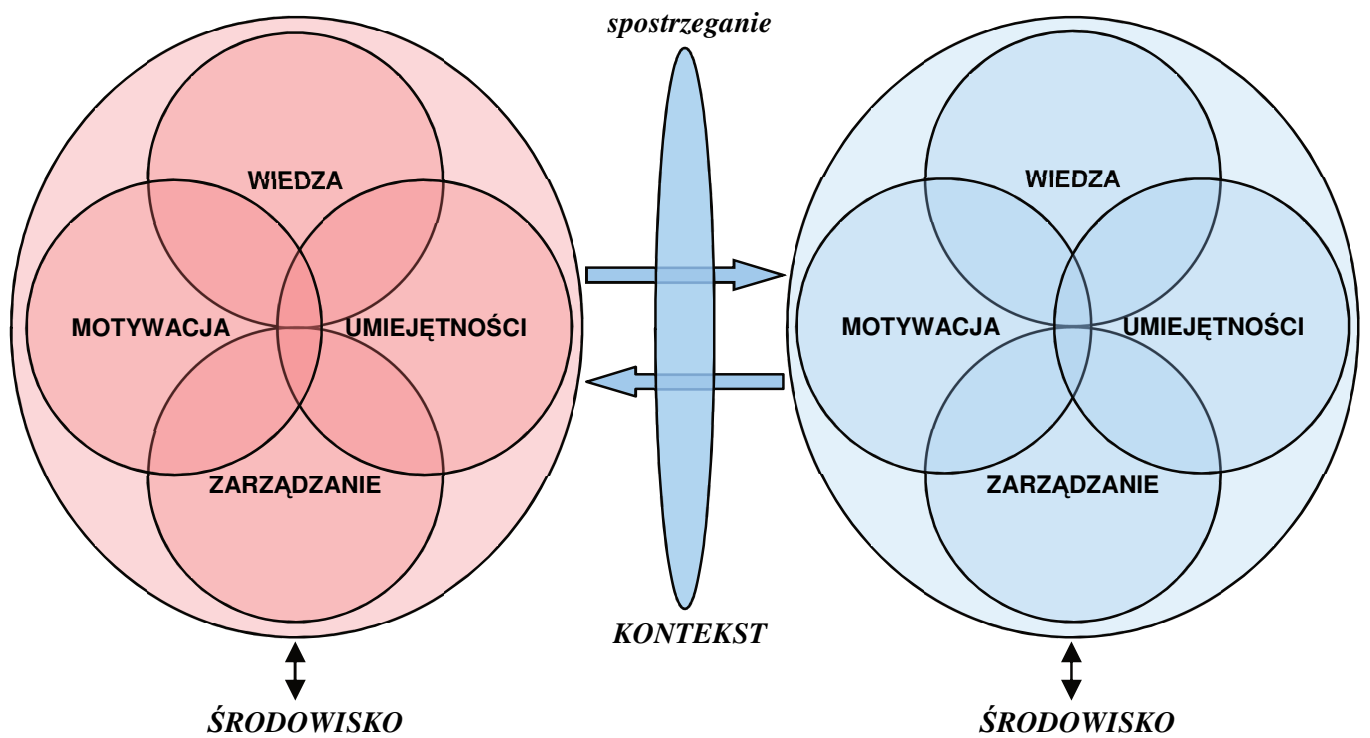

Rys. 1. Cztero-elementowy model kompetencji językowo - komunikacyjnej opracowany w oparciu o model wg Morreale'a, Spitzberga i Barge'a (2007)

Prezentowany powyżej model kompetencji językowo-komunikacyjnej przyjmuje założenie, że komunikacja ma charakter transakcyjny, co przejawia się wymiennością ról odbiorcy i nadawcy, a każdy przekaz otrzymuje sprzężenie zwrotne. Model ten, podobnie jak model Gerbnera, wyłania element transformacji obiektywnej rzeczywistości poprzez proces percepcji. Dzięki niej uczestnicy komunikacji selekcjonują i interpretują bodźce i sygnały komunikacyjne według subiektywnych wartości, potrzeb i celów.

Każdy uczestnik interakcji jest wyposażony w zasoby wiedzy, umiejętności oraz motywację. Poziom zasobów wpływa na jakość umiejętności, które ujawniają się w różnych spotkaniach komunikacyjnych. 
Zasoby wiedzy i umiejętności obejmują wiedzę i umiejętności metakomunikacyjne, mechanizmy kognitywne oraz wiedzę i umiejętności stricte językowo-komunikacyjne sformułowane w oparciu o definicję kompetencji komunikacyjnej w ujęciu ekolingwistycznym Stanisława Puppla (2004: 6 - tłumaczenie własne - J.F-P.), tj. jako suma kompetencji językowo-komunikacyjnej (ang. 'linguistic communicative competence' - 'LCCom'), kompetencji komunikacyjnej niejęzykowej (ang. 'non-linguistic communicative competence' - 'nLCCom') oraz takich czynników jak skłonności komunikacyjne danych społeczności komunikacyjnych, do których należy dany komunikator ('Con 1'), idiosynkratyczne cechy komunikatora ('Con 2'), takie jak: wiek, wykształcenie, stan zdrowia, charakterystyczne cechy głosu, stan emocjonalny, stan intelektualny, etc., bieżący kontekst użycia środków językowych i niejęzykowych.

W tym rozumieniu kompetencja komunikacyjna składa się z kompetencji językowo-komunikacyjnej i niejęzykowej języka rodzimego, kompetencji językowo-komunikacyjnej i niejęzykowej języka obcego oraz dodatkowych czynników wymienionych powyżej.

Nauczyciel, jako jeden z komunikatorów w ekosystemie szkolnym, aktywnie wykorzystuje swoją kompetencję językowo-komunikacyjną w procesie nauczania. Czas ekspozycji ucznia na tę komunikację w polskiej współczesnej szkole jest na tyle duży (średnio około 35 godzin tygodniowo), że należy ocenić nauczyciela jako jednego z głównych źródeł i wzorców językowo-komunikacyjnych młodego komunikatora. Według badań przeprowadzonych $\mathrm{w}$ ramach pracy doktorskiej autorki (Filar-Pieczkowska, 2014) na grupie 192 uczniów w prywatnej szkoły językowej wynika, że około $76 \%$ uczniów zwraca uwagę na sposób wypowiedzi swojego nauczyciela języka angielskiego i podobny odsetek, bo aż 75\%, dostrzega nauczycielskie różnicowanie środków językowych. Natomiast mniejszy odsetek uczniów (53\%) potwierdziło, że zwraca uwagę na użycie zasobów niewerbalnych nauczyciela, co można przypisać bądź mniejszej uważności na takie sygnały bądź obserwacji w sposób nieświadomy.

W świetle wyżej podanych wyników badań należy zadać pytanie: Czy nauczyciel języka angielskiego może pełnić aktywną rolę w procesie umocnienia tężyzny języka rodzimego?

Przyjmując za Pupplem $(2007,2011)$, że transkomunikacja rozwija umiejętności językowo-komunikacyjne oraz doskonali kompetencję kulturowo-językowo-komunikacyjną zarówno języka rodzimego, jak i języka drugiego można wskazać tę formę kontaktu językowego jako optymalną do wykorzystania na zajęciach nauki języka angielskiego. Nauka dwóch języków (rodzimego i nierodzimego - w tym przypadku angielskiego i polskiego) na zasadzie TRANS - zakłada traktowanie i używanie ich jako równych sobie, o świadomościowym statusie języków adstratowych, co wspiera ich symultaniczny rozwój (ibid.). Z perspektywy celów pedagogicznych transkomunikacja nie zawęża procesu nauczania i uczenia się języka 
obcego do morfologii, fonologii i składni, lecz przede wszystkim postrzegana jest w szerszym znaczeniu jako sposób doskonalenia umiejętności komunikacyjnych, gdzie język nierodzimy jest traktowany jako dodatkowe narzędzie komunikacyjne.

Nauczyciel jako inicjator komunikacji na lekcjach języka obcego może prowadzić dwutorowy proces nauczania oparty na stopniowym dodawaniu elementów kompetencji językowo-komunikacyjno-kulturowej języka nierodzimego (w tym przypadku angielskiego) do stabilnej podstawy kompetencji językowo-komunikacyjno-kulturowej języka rodzimego (w tym przypadku polskiego). W oparciu o ten model działania uczniowie - komunikatorzy utrwalają sobie wzorzec kontaktów językowo-kulturowych dwóch systemów językowo-komunikacyjno-kulturowych o równorzędnej wartości i statusie.

Zatem celem edukacyjnym działań nauczycieli powinno być ukształtowanie ucznia jako silnego komunikatora z zakorzenioną świadomością bogactwa swojego rodzimego języka i kultury, jednocześnie poszerzającego swój repertuar kulturowo-językowo-komunikacyjny języka nierodzimego jako dodatkowe narzędzie komunikacyjne (Puppel i Puppel, 2005). Biorąc pod uwagę silny transakcyjny charakter komunikacji nauczyciel - uczeń, obowiązkiem nauczyciela (jako inicjatora i moderatora tego procesu) jest dbałość o wzbogacanie swoich zasobów językowych i pozajęzykowych oraz zarządzanie nimi w sposób odpowiedni, skuteczny i ekologiczny, ponieważ w wyniku wymienności tychże zasobów i stylu zarządzania jest on odpowiedzialny za profilowanie ucznia jako komunikatora. W kontekście nauczania języka obcego w nurcie transkomunikacyjnym, zasoby językowe i pozajęzykowe dotyczą obu języków - języka rodzimego i języka nierodzimego wraz z ładunkiem kulturowym, który jest ich integralną częścią (Filar-Pieczkowska, 2015).

\section{Podsumowanie}

Współczesny człowiek funkcjonujący w zglobalizowanym świecie, w którym „zespół procesów (...) tworzy jeden wspólny świat” (Kempny, 1998: 241) powinien być świadomym komunikatorem. Codziennie jesteśmy bombardowani informacjami, aktualnościami, trendami, poglądami z różnych stron świata, z różnych kultur i w różnych językach. I tylko świadomy komunikator wyposażony w wiedzę, umiejętności, motywację i zarządzający w sposób optymalny do kontekstu będzie umiał selektywnie odebrać napływające komunikaty i stworzyć komunikat zwrotny.

Na podstawie wstępnych badań można wysnuć hipotezę, że ekosystem szkolny stanowi sprzyjające środowisko do kształtowania kompetencji językowo-komunikacyjnej ucznia, a rola nauczyciela w tym procesie ma charakter ,aktywatora” lub „promotora”. Świadomy komunikator-nauczyciel, zarządzając odpowiednio swoimi zasobami wiedzy, umiejętności i motywacji, modeluje kompetencję językowo-komunikacyjną ucznia/uczniów. Przy czym kompetencja językowo-komunikacyjna 
w kontekście lekcji języka obcego obejmuje zarządzanie zasobami wiedzy, umiejętności i motywacją w ramach zasobów werbalnych i niewerbalnych języka rodzimego i języka nierodzimego. Co więcej, nauczyciel języka angielskiego promujący edukację językowa ukierunkowaną na transkomunikację kształtuje wśród uczniów postawy z rozwiniętą świadomością kulturowo-językowo-komunikacyjną, w wyniku czego język rodzimy zyskuje tężyznę, a to z kolei zabezpiecza żywotność jak największej liczby języków naturalnych na globalnej arenie języków naturalnych.

Globalizacja jako proces intensyfikacji stosunków społecznych o globalnym zasięgu powoduje poczucie „kurczenia się świata” przy jednoczesnym „poszerzeniu świadomości świata jako całości” (Kempny, 1998: 224). Kształtując tę świadomość wśród współczesnych młodych komunikatorów można uniknąć albo zminimalizować negatywny wpływ globalizacji, a wykorzystać jej pozytywne wartości. Niewykluczone, że nauczyciel języka angielskiego wraz ze swoimi kompetencjami językowo-komunikacyjnymi może w tym procesie odegrać aktywną i dość znaczącą rolę, co upoważnia do postrzegania jego pracy i kompetencji jako wciąż istotnych we współczesnym zglobalizowanym świecie.

\section{Bibliografia}

Cybal-Michalska, A. i T. Gmerek. 2015. „Globalizacja - aspekt edukacyjny i socjalizacyjny”. W zbiorze: Pyżalski, J. (red.). Wychowawcze i społeczno-kulturowe kompetencje współczesnych nauczycieli. Wybrane konteksty. Łódź: The QStudio. 9-30.

Filar-Pieczkowska, J. 2014. Rozwój kompetencji językowo-komunikacyjnej ucznia języka angielskiego w ekosystemie szkolnym na przykładzie polskiej prywatnej szkoły językowej. Nieopublikowana rozprawa doktorska. Poznań: Uniwerystet im. Adama Mickiewicza w Poznaniu.

Filar-Pieczkowska, J. 2015. „Rozwój kompetencji językowo-komunikacyjnej ucznia języka angielskiego w ekosystemie szkolnym na przykładzie polskiej prywatnej szkoły językowej”. W zbiorze: Puppel, S. (red.). MOTEK. Motywy ekolingwistyczne: w stronę ekoglottodydaktyki. Poznań: Katedra Ekokomunikacji UAM. 31-50.

Kempny, M. 1998. „Globalizacja. Spór o naturę globalizacji”. W zbiorze: Bokszański, Z. i A. Kojder (red.). Encyklopedia socjologii. T.1. Warszawa: Oficyna Naukowa.

Morreale, S.P, Spitzberg, B.H. i J.K. Barge. 2007. Komunikacja między ludźmi. Motywacja, wiedza i umiejętności. Warszawa: Wydawnictwo Naukowe PWN.

Puppel, S. 2004. „An outline of domain-resource-agent-access-managment (DRAAM) model of human communication: towards an ecology of human communication”. Oikeios Logos 1. 1-26.

Puppel, S. i J. Puppel. 2005. „Zagadnienie percepcji języka naturalnego w triadzie: język ojczysty-język globalny-język sąsiedni na przykładzie triady: język polski-język angielski-język niemiecki w ujęciu ekolingwistycznym: próba typologii”. Scripta Neophilologica Posnaniensia VII. 55-95.

Puppel, S. 2007. „Interlingwalizm czy translingwalizm? Interkomunikacja czy transkomunikacja? Uwagi w kontekście współistnienia języków naturalnych w ramach globalnej wspólnoty kulturowo-językowo-komunikacyjnej”. W zbiorze: Puppel, S. (red.). Społeczeństwo-kultura-język. W stronę interakcyjnej architektury komunikacji. Poznań: Katedra Ekokomunikacji UAM. 81-94. 
Puppel, S. 2009. „The protection of natural language diversity - fancy or duty?”. Scripta Neophilologica Posnaniensia X. 97-109.

Puppel, S. 2011. „The universal natural language preservation mechanism: an ecological approach”. W zbiorze: Puppel, S. (red.). Transkomunikacja. W stronę sprofilowania przestrzeni publicznej jako wielopłaszczyznowej przestrzeni komunikacyjnej. Poznań: Katedra Ekokomunikacji UAM. 91-99.

Tobera, P. 2000. „Niepokojąca nowoczesność”. Kultura i spoteczeństwo 3. 10-25. 